\title{
The Tin Man finally gets his heart
}

\author{
Alden H. Harken, MD, FACS \\ From the Department of Surgery, University of California, Oakland, Calif. \\ Disclosures: Author has nothing to disclose with regard to commercial support. \\ Received for publication May 30, 2017; accepted for publication June 5, 2017; available ahead of print July 1, \\ 2017. \\ Address for reprints: Alden H. Harken, MD, FACS, Department of Surgery, University of California, San \\ Francisco-East Bay, 1411 E 31st St (QIC 22134), Oakland, CA 94602 (E-mail: alden.harken@ucsfmedctr.org). \\ J Thorac Cardiovasc Surg 2017;154:949-50 \\ $0022-5223 / \$ 36.00$ \\ Copyright (C) 2017 by The American Association for Thoracic Surgery \\ http://dx.doi.org/10.1016/j.jtcvs.2017.06.008
}

Heart transplantation is limited not only by availability of donor organs but also by donor organ access, which usually mandates a flight in a cold airplane at night and a dispute with the liver team over the length of the inferior vena cava. So, the quest for alternative organ sources is a high priority. Dr Shumway famously decreed, "Xenotransplantation is just around the corner and always will be." So, growing organs has intuitive appeal, but it has also faced cell-biological, immunologic, tissue engineering, political, and ethical hurdles.

On July 5, 1996, "Dolly" was born after a successful "nuclear transfer." Scientists at the Roslin Institute started with an oocyte (unfertilized egg) and removed all the chromosomes. They then fused an adult cell, with a full set of chromosomes, into the "carrier" egg, activated it, and transferred this package into a surrogate mother's uterus. Five months later: Voilà, Dolly! The sociopolitical and ethical barriers to producing autologous human isograft organs by this strategy are, of course, insurmountable. But the possibility of "fooling" with pluripotent stem cells to grow organs (or cells of organs) began to seem feasible.

Investigators began working with adult stem cells, typically bone marrow-derived stem cells, with disappointing results. Multiple groups have now produced phenotypically unambiguous cardiomyocytes from pluripotent stem cells. When these cells are injected into a zone of infarcted myocardium, they gratifyingly appear to fly in formation. ${ }^{1}$ But, until recently, reprogramming adult somatic cells obligated gene delivery via integration of viral vectors. Even friendly viruses, however, seem to stir up some smoldering inflammation.

Shinya Yamanaka and colleagues then accomplished the magical orbital jump by successfully reprogramming differentiated cells derived from the facial dermis of a 36-year-old white woman into a pluripotent state by

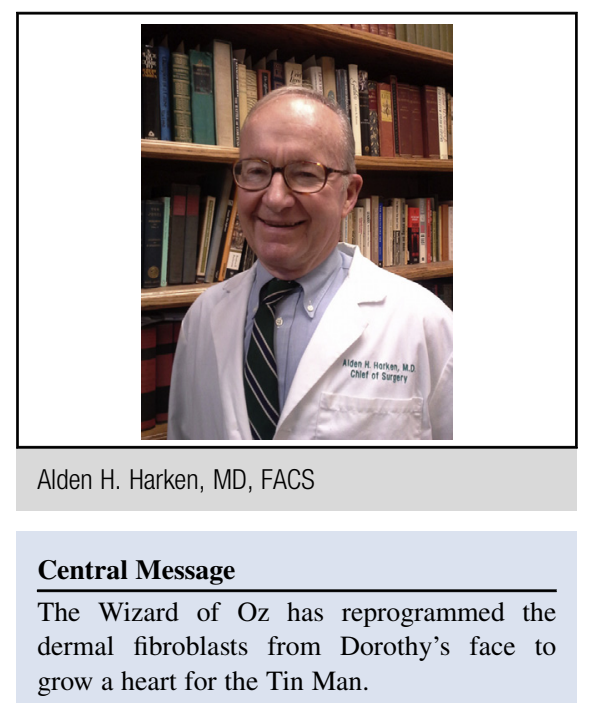

See Article page 945.

transduction of only 4 defined transcription factors. ${ }^{2}$ "These human induced pluripotent stem cells (iPSCs) were similar to human embryonic stem cells in morphology, proliferation, gene expression, epigenetic status of pluripotent cell specific genes and telomerase activity." ${ }^{2}$ Or, more simply, induced pluripotent stem cells were generated from the fibroblasts of this nice lady's face.

Now, induced pluripotent stem cell cardiomyocyte transplantation can accomplish robust and durable enhancement of ventricular contractile function in a large animal infarct model. ${ }^{3}$ The authors also tout these induced pluripotent stem cells as a potentially useful model for addressing immunologic issues associated with allotransplantation. Not surprisingly, there remain some irritating chinks in this Holy Grail. Electrophysiologists have recognized for years that the 3 essential substrates of reentrant cardiac dysrhythmias are slow conduction, rapid refractoriness, and heterogeneous tissue. Sprinkling viable cardiomyocytes into a sea of postinfarction fibrosis creates the kind of heterogeneous cellular matrix that favors the circuitous pathway of a reentrant impulse-and ventricular tachycardia.

So, the Tin Man's heart may flutter—but he's finally got a heart. 


\section{References}

1. Masoudpour H, Laflamme M. Cardiac repair with pluripotent stem cell-derived cardiomyocytes: proof-of-concept but new challenges. J Thorac Cardiovasc Surg. 2017; 154:945-8.

2. Takahashi K, Tanabe K, Ohnuki M, Narita M, Ichisaka T, Tomoda K, et al. Induction of pluripotent stem cells from adult human fibroblasts by defined factors. Cell. 2007;131:861-72.
3. Shiba Y, Gomibuchi T, Seto T, Wada Y, Ichimura H, Tanaka Y, et al. Allogeneic transplantation of iPS cell-derived cardiomyocytes regenerates primate hearts. $\mathrm{Na}$ ture. 2016;20:388-91. 